\title{
Application of internal transcribed spacer (ITS) sequences for identifying Anoectochilus setaceus Blume in Thanh Hoa, Vietnam
}

\author{
DOI: $10.30901 / 2227-8834-2020-2-108-116$ (cc) BY \\ УДК 582.52:575:581.9 \\ Поступление/Received: 11.03 .2020 \\ Принято/Accepted: 09.06.2020 \\ B. B. THINH ${ }^{1 *}$, L. D. CHAC ${ }^{2}$, L. T. M. THU ${ }^{3}$ \\ ${ }^{1}$ School of Natural Sciences, Far Eastern Federal University, \\ 10 Ajax Bay, Russky Island, Vladivostok 690922, Russia \\ ${ }^{2}$ Faculty of Natural Sciences, Hong Duc University, \\ 565 Quang Trung Street, Thanh Hoa 40130, Vietnam \\ ${ }^{3}$ Faculty of Natural Sciences and Technology, \\ Tay Bac University, \\ Quyet Tam Dist., Son La 34114, Vietnam \\ * buibaothinh9595@gmail.com
}

\author{
Применение последовательностей \\ внутренних транскрибируемых спейсеров \\ (ITS) для идентификации образцов \\ Anoectochilus setaceus Blume \\ в Тханьхоа (Вьетнам) \\ Б. Б. ТХИНЬ ${ }^{1 *}$, Л. Д. ЧАК ${ }^{2}$, Л. Т. М. ТХУ ${ }^{3}$ \\ ${ }^{1}$ Школа естественных наук, \\ Дальневосточный федеральный университет, \\ 690922 Россия, г. Владивосток, о. Русский, п. Аякс, 10 \\ ${ }^{2}$ Факультет естественных наук, Университет Хонгдык, \\ 565 ул. Куанг Чунг, г. Тханьхоа 40130, Вьетнам \\ ${ }^{3}$ Факультет естественных наук и технологий, \\ Университет Тайбак, \\ р-н Куиэт Там, г. Шонла 34114, Вьетнам \\ * buibaothinh9595@gmail.com
}

Background. The term "DNA barcode" is used extensively in molecular taxonomy. Basically, this technique is based on the use of a DNA sequence (about 400-800 bp) as a standard to identify and determine the species relation of organisms quickly and accurately. Therefore, DNA barcodes not only help taxonomists in classifying and identifying species, but also improve their ability to control, understand and utilize biodiversity. In this study, the authors conducted identification of samples of Anoectochilus setaceus Blume collected in Thanh Hoa through the isolated sequence of ITS gene regions. Materials and methods. Total DNA was extracted from young leaves of $A$. setaceus samples using CTAB method. The ITS gene segment was amplified by PCR and sequenced. This genetic sequence was analyzed, compared and used to establish a phylogenetic tree using BioEdit, BLAST and DNASTAR programs. Results and conclusion. We isolated 4 sequences of the ITS gene region in 4 A. setaceus samples collected at Xuan Lien and Pu Luong of Thanh Hoa province; the ITS gene region was 667 nucleotide long. The findings identified the samples as the same species and showed $99 \%$ similarity to the ITS gene sequence of $A$. roxburghii (Wall.) Lindl. published in GenBank, GQ328774. This study also demonstrates that the method employing internal transcribed spacer (ITS) sequences is an effective tool to identify $A$. setaceus taxa.

Key words: molecular taxonomy, DNA barcoding, ITS primers, identification of samples.
Актуальность. Термин «DNA barcode» широко используется в молекулярной таксономии. По существу, этот метод основан на использовании последовательности ДНК (около 400-800 пн) в качестве стандарта для быстрой и точной идентификации и определения видовых отношений организмов. Таким образом, ДНК-штрихкоды помогают систематикам не только классифицировать и идентифицировать виды, но и контролировать, понимать и использовать биоразнообразие. В настоящем исследовании авторы провели идентификацию образцов Anoectochilus setaceus Blume, собранных в провинции Тханьхоа, на основе анализа последовательностей ITS. Материалы и методы. Тотальную ДНК выделяли из молодых листьев образцов A. setaceus с использованием бромида цетилтриметиламмония (СТАВ-метод). Сегмент гена ITS амплифицировали методом ПЦР и секвенировали. Эту генетическую последовательность анализировали, сравнивали и использовали для построения «филогенетичеческого древа» с помощью программ BioEdit, BLAST, DNASTAR. Результаты и выводы. Нами выделены 4 последовательности генной области ITS из 4 образцов A. setaceus, собранных в Сюань Лиен и Пу Луонг провинции Тханьхоа; изученный ITS-регион имел длину 667 нуклеотидов. Полученные данные идентифицировали образцы как один и тот же вид и показали 99-процентное сходство с последовательностью ITS A. roxburghii (Wall.) Lindl., опубликованной в базе данных GenBank (GQ328774). Исследование также демонстрирует, что использование внутреннего транскрибируемого спейсера (ITS) является эффективным методом для идентификации образцов A. setaceus.

Ключевые слова: молекулярная таксономия, баркодирование ДНК, праймеры ITS, идентификация образцов.

\section{Introduction}

In medical terms, Anoectochilus setaceus Blume is a powerful medicinal orchid which has functions beneficial for human health, i.e., improving blood circulation, producing antibacterial, anti-tracheitis, anti-hepatitis, and anti-neurasthenia effects (Lin et al., 1993; Lin et al., 2000; Wang et al., 2002;
Ye et al., 2017). In particular, some active substances in $A$. setaceus are able to stop the growth of cancer cells. The chemical constituents of $A$. setaceus include quercetin, isoharmnetin3-0-beta-D-glucopyranosid, kaempferol-3-0-beta-D-glucopyranosid, 5-hydroxy-3'-4'-7'-trimethoxyflavonol-3-0-beta-Drutinosid and isorhamnetin-3-0-beta-D-rutinosid, etc. (He et al., 2006; Ye et al., 2017; Chac et al., 2019). Because of its 
medicinal values, $A$. setaceus is popular in the market and sold at a high price. The small population of plants which scatters in a few highland forests, and illegal exploitation have made A. setaceus listed in the Vietnam Red Data Book (Vietnam Academy of Science and Technology, 2007). As a result, all exploitation and use of A. setaceus for illegal commercial purposes are banned in Vietnam.

The internal transcribed spacer (ITS) regions are localized between nuclear genes coding for 18S, 5.8S and 26S rRNA (Kress et al., 2005). Among the gene units are ITS1 and ITS2 segments, which form a basic gene group. Such gene groups replicate continuously in thousands of copies in the nucleus genes while being separated by the nontranscribed spacer region. In plant classification studies at the species level, ITS region is the most commonly decoded locus (Gigliano, 1999; Li D.Z. et al., 2011; Takamiya et al., 2011; Tripathi et al., 2013). The ITS region has been shown to be highly effective in classification of plants and fungi (except for ferns). This is a locus used for short DNA sequencing (Stoeckle, 2003; Chen, Shiau, 2015). It was demonstrated in most studies that the ITS region had a wide diversity (about 13.6\% among closely related species) at the species level (Li M. et al., 2011; Techen et al., 2014; Lv et al., 2015; Hu et al., 2019). One of the advantages of the ITS region is that it can replicate two smaller segments (ITS1 and ITS2) on both sides with the 5.8S locus, which is useful in case of replicating damaged samples. It was also pointed out that the ITS region had low levels of variation within the species (Baldwin et al., 1995; Yang et al., 2012; Wang et al., 2020). That more than 100 thousand ITS sequences (until June 2016) have been published and the new figures continue to be added to the GenBank database is now a valuable source for studies on species.

A. setaceus in Vietnam is in danger of extinction because of its small and sparse population mainly in the forests as well as its overexploitation by humans. Moreover, the regeneration ability of this species is very low in the wild, especially where the ecological environment is devastated. As a result, the conservation and development of this species is a key and necessary issue. Thus, it is important to isolate and read ITS genome sequences and $A$. setaceus genotypes to provide important scientific data for the conservation, development and appropriate exploitation of this rare and precious medicinal herb.

\section{Materials and methods}

\section{Plant materials}

From March 2018 to May 2018, a total of 4 Anoectochilus setaceus samples were collected from Xuan Lien National Park and Pu Luong Nature Reserve in Thanh Hoa Province, Vietnam. Specifically, two samples (XL1 and XL2) were collected in Xuan Lien National Park and the other two (PL1 and PL2) were collected in Pu Luong Nature Reserve. Samples of young leaves were collected, stored in paper bags with silica gel, then moved to the laboratory and kept in a freezer at a temperature of $-20^{\circ} \mathrm{C}$ for DNA extraction. Species identification of collected samples was performed by Associate
Professor Tran Minh Hoi (Institute of Ecology and Biological Resources, Vietnam Academy of Science and Technology) on the basis of morphological characteristics. In addition, 1 ITS sequence of $A$. roxburghii (Wall.) Lindl. (GQ328774) and 1 ITS sequence of $A$. lanceolatus Lindl. (KT344108) were downloaded from the GenBank database.

\section{Total DNA extraction}

Total DNA was extracted from the young leaves of $A$. setaceus samples using CTAB method (Doyle, Doyle, 1987) with some improvement.

Step 1: Put $200 \mathrm{mg}$ of young leaves in liquid nitrogen $\left(-196^{\circ} \mathrm{C}\right)$ to grind into a fine powder. Add $6 \mathrm{ml}$ wash buffer (Tris - $\mathrm{HCl} 100 \mathrm{mM}, \mathrm{pH}=8.0$; EDTA $5 \mathrm{mM}, \mathrm{pH}=8.0$; $\mathrm{NaH}_{2} \mathrm{PO}_{4}$ 0.4\%; sorbitol $350 \mathrm{mM}$; water). Transfer to $1.5 \mathrm{ml}$ Eppendorf tube. Centrifuge the sample for 15 minutes, at a speed of 12000 rounds per minute at $4^{\circ} \mathrm{C}$, remove the fluid, and collect the sediment.

Step 2: Add $500 \mu \mathrm{l}$ of extraction buffer to each tube (components of the buffer: Tris - $\mathrm{HCl} 100 \mathrm{mM}, \mathrm{pH}=8.0$; EDTA $20 \mathrm{mM}, \mathrm{pH}=8.0$; CTAB 4\%; $\mathrm{NaCl} 1.4 \mathrm{M}$; water), mix gently, incubate at $65^{\circ} \mathrm{C}$ for 30 minutes (gently stir every 15 minutes). After finishing the incubation, leave the sample under room temperature for 5 minutes.

Step 3: Centrifuge for 15 minutes, at a speed of 12000 rounds per minute at $4^{\circ} \mathrm{C}$. Transfer the aqueous upper phase to a new $1.5 \mathrm{ml}$ Eppendorf tube.

Step 4: Add $500 \mu \mathrm{l}$ of C : I ( 24 chloroform : 1 isoamyl) to remove protein and impurities, stir for 15 minutes. Centrifuge for 15 minutes, at a speed of 12000 rounds per minute at $4^{\circ} \mathrm{C}$. Carefully suck $500 \mu \mathrm{l}$ of clear liquid in the upper phase and transfer to a new $1.5 \mathrm{pl}$ Eppendorf tube (remove precipitate). Repeat this step twice.

Step 5: Add $500 \mu \mathrm{l}$ of isopropanol, mix gently, precipitate the DNA at $-20^{\circ} \mathrm{C}$ overnight. Then centrifuge for 15 minutes, at a rate of 12000 rounds per minute at $4^{\circ} \mathrm{C}$, collect the precipitate.

Step 6: Add $500 \mu \mathrm{l}$ of $70 \%$ ethanol. Centrifuge for $10 \mathrm{~min}$ utes, 12000 rounds per minute at $4^{\circ} \mathrm{C}$, decant the precipitate (repeat 2-3 times). Dry at room temperature and dissolve DNA in $50 \mu \mathrm{l}$ of distilled water twice. Store in the freezer at $-20^{\circ} \mathrm{C}$ until use.

\section{ITS gene amplification via PCR technique}

The ITS gene fragments amplified via PCR technique with ITSF / ITSR specific primers were obtained on T100 Thermal Cycler Bio-Rad PCR machine (Table 1). The amplified ITS gene fragment was expected to be about 700 nucleotides long. The reaction was carried out with a total volume of $25 \mu \mathrm{l}$, including $12.5 \mu \mathrm{l}$ Maxter Mix 2X (Thermo Scientific), $1 \mu \mathrm{l}$ for each primer, $1 \mu \mathrm{l}$ DNA template and $9.5 \mu \mathrm{l}$ deionized water. The PCR cycle included denaturation starting at $94^{\circ} \mathrm{C}$ for 4 minutes; repeated 25 cycles including: denaturing at $94^{\circ} \mathrm{C}$ for 30 seconds, attaching primer at $55^{\circ} \mathrm{C}$ for 40 seconds, synthesizing and lasting at $72^{\circ} \mathrm{C}$ for 40 seconds. The process ended by exposing it to $72^{\circ} \mathrm{C}$ for 10 minutes and storing at $4^{\circ} \mathrm{C}$.

Table 1. ITS primers used for PCR amplification

Таблица 1. Праймеры, использованные для амплификации района ITS

\begin{tabular}{|l|c|l|c|}
\hline \multicolumn{2}{|c|}{ Primer code } & \multicolumn{1}{|c|}{$\begin{array}{c}\text { Sequence } \\
\left(5^{\prime} \rightarrow \mathbf{3}^{\prime}\right)\end{array}$} & Source \\
\hline \multirow{2}{*}{ ITS } & $\mathrm{F}$ & AGGAGAAGTCGTAACAAGGTTTCC & $\begin{array}{c}\text { Macrogen } \\
\text { (South Korea) }\end{array}$ \\
\cline { 2 - 3 } & $\mathrm{R}$ & GATATGCTTAAACTCAGCGGGTC & \\
\hline
\end{tabular}




\section{Electrophoresis for PCR product testing}

The PCR products were electrophoresed on $0.8 \%$ agarose gel. The gels were then removed from the electrophoresis equipment and gently transfered to a container with ethidium bromide solution, in which they were stained for 10 minutes. The gels were washed by being soaked in water for 2-3 minutes before being put into a machine for ultraviolet (UV) light observation and taking photos.

\section{Purification of PCR products}

The next step after amplification should be collecting the genes in a pure and gel-free form. Purification was conducted using Kit GenJET PCR Purification of Thermo Scientific.

\section{Determination of the order of the nucleotides within an ITS gene}

The order of the nucleotides within an ITS gene was determined on the ABI PRISM® 3100 Avant Genetic Analyzer, using the BigDye ${ }^{\circledR}$ Terminator v3.1 Cycle Sequencing Kit with specific primers. The gene sequence was analyzed and compared, and a phylogenetic tree was established using BioEdit, BLAST, DNASTAR.

\section{Results and discussion}

ITS gene amplification of $A$. setaceus samples

After being amplified using PCR techniques, the ITS gene of $A$. setaceus samples were electrophoresed on $0.8 \%$ agarose gel and photographed. PCR results with specific primer pairs are shown in Fig. 1.

\section{$\begin{array}{lllll}1 & 2 & 3 & 4 & M\end{array}$}

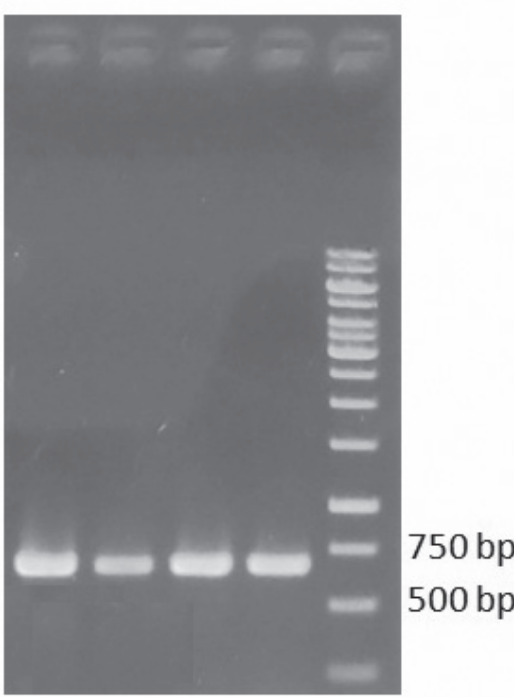

Fig. 1. PCR results with ITS primer pair for 4 Anoectochilus setaceus samples. M - Molecular weight marker; 1 - XL1, 2 - XL2; 3 - PL1; 4 - PL2

Рис. 1. Результаты ПЦР 4-х образцов Anoectochilus setaceus с использованием пары ITS-праймеров. М - Маркер молекулярного веса; 1 - XL1, 2 - XL2; 3 - PL1; 4 - PL2

The result of electrophoresing 4 samples with ITS F/R primers was a single band at about $700 \mathrm{bp}$. This result was consistent with theoretical calculations and served as a basis in terms of ITS gene sequencing for further research.
Determination of the ITS gene sequence of $A$. setaceus samples

After electrophoresis, ITS gene sequencing was conducted on the ABI PRISM $® 3100$ Avant Genetic Analyzer, using the BigDye ${ }^{\circledR}$ Terminator v3.1 Cycle Sequencing Kit with specific primers. The findings were as follows:

\section{Pu Luong 1 ITS sequence (PL1)}

GGGAAAAAGACCCTAAAGAGGATGGATGACTTTGGATA ACACGTGAACATTTGACGGCGGTTGCTGTCTATAAACACCAT CCATCTATTGGCCCCTCTTGATTGAGGCAACAATAAAAAGAT GGAGGGAAAAACAACTCGGGCGCAGTTGTGCGCCAAGGAAG TATGTTGCATTGGCATCGATGACTATTCGCCAAAGCCTGTCG TGCTTAGCGGAGTGTTGTTGTTGCTTCTTAAGTATTGTATGA CTCTCGGCAATGGATATCTTGGCTCTTGCATCGATGAAGAGC GCAGCGAAATGCGATACGTGGTGTGAATTGCAGAATCCCGTG AACCATCAAATCTTTGAACGCAAGTTGCGCCTGAGGCCAAT TGGCTAAGGGCACGTCCGCCTGGGCGTCAAGCATTACATCGC TTCATTCGACACCAATTGCCCAGTATTTTGCTGTGGTGCTGG TCTGAATGCGGAGAGTGGCCCTTCGTGCACACTTGTGCGACG GGTTGAAGAACAATTTGCTTTCCTCTGGCCATGTTTTGATA AAGGGGTGGTGTATGCAGCCATTAGGCCCACACTATCATCTC ATTGCCTTGAGGAGGATAAATGTACACATTCGTGGCTGATCA CCCGATATAAATGTCGCAGGTGACGCCCTGAAATGCGACCC CA

Pu Luong 2 ITS sequence (PL2)

GGGAAAAAGACCCTAAAGAGGATGGATGACTTTGGATA ACACGTGAACATTTGACGGCGGTTGCTGTCTATAAACACCAT CCATCTATTGGCCCCTCTTGATTGAGGCAACAATAAAAAGAT GGAGGGAAAAACAACTCGGGCGCAGTTGTGCGCCAAGGAAG TATGTTGCATTGGCATCGATGACTATTCGCCAAAGCCTGTCG TGCTTAGCGGAGTGTTGTTGTTGCTTCTTAAGTATTGTATGA CTCTCGGCAATGGATATCTTGGCTCTTGCATCGATGAAGAGC GCAGCGAAATGCGATACGTGGTGTGAATTGCAGAATCCCGTG AACCATCAAATCTTTGAACGCAAGTTGCGCCTGAGGCCAAT TGGCTAAGGGCACGTCCGCCTGGGCGTCAAGCATTACATCGC TTCATTCGACACCAATTGCCCAGTATTTTGCTGTGGTGCTGG TCTGAATGCGGAGAGTGGCCCTTCGTGCACACTTGTGCGACG GGTTGAAGAACAATTTGCTTTCCTCTGGCCATGTTTTGATA AAGGGGTGGTGTATGCAGCCATTAGGCCCACACTATCATCTC ATTGCCTTGAGGAGGATAAATGTACACATTCGTGGCTGATCA CCCGATATAAATGTCGCAGGTGACGCCCTGAAATGCGACCC CA

Xuan Lien 1 Sequence (XL1)

GGGAAAAAGACCCTAAAGAGGATGGATGACTTTGGATA ACACGTGAACATTTGACGGCGGTTGCTGTCTATAAACACCAT CCATCTATTGGCCCCTCTTGATTGAGGCAACAATAAAAAGAT GGAGGGAAAAACAACTCGGGCGCAGTTGTGCGCCAAGGAAG TATGTTGCATTGGCATCGATGACTATTCGCCAAAGCCTGTCG TGCTTAGCGGAGTGTTGTTGTTGCTTCTTAAGTATTGTATGA CTCTCGGCAATGGATATCTTGGCTCTTGCATCGATGAAGAGC GCAGCGAAATGCGATACGTGGTGTGAATTGCAGAATCCCGTG AACCATCAAATCTTTGAACGCAAGTTGCGCCTGAGGCCAAT TGGCTAAGGGCACGTCCGCCTGGGCGTCAAGCATTACATCGC TTCATTCGACACCAATTGCCCAGTATTTTGCTGTGGTGCTGG TCTGAATGCGGAGAGTGGCCCTTCGTGCACACTTGTGCGACG GGTTGAAGAACAATTTGCTTTCCTCTGGCCATGTTTTGATA AAGGGGTGGTGTATGCAGCCATTAGGCCCACACTATCATCTC ATTGCCTTGAGGAGGATAAATGTACACATTCGTGGCTGATCA CCCGATATAAATGTCGCAGGTGACGCCCTGAAATGCGACCC CA

Xuan Lien 2 Sequence (XL2)

GGGAAAAAGACCCTAAAGAGGATGGATGACTTTGGATA ACACGTGAACATTTGACGGCGGTTGCTGTCTATAAACACCAT CCATCTATTGGCCCCTCTTGATTGAGGCAACAATAAAAAGAT GGAGGGAAAAACAACTCGGGCGCAGTTGTGCGCCAAGGAAG TATGTTGCATTGGCATCGATGACTATTCGCCAAAGCCTGTCG 
TGCTTAGCGGAGTGTTGTTGTTGCTTCTTAAGTATTGTATGA CTCTCGGCAATGGATATCTTGGCTCTTGCATCGATGAAGAGC GCAGCGAAATGCGATACGTGGTGTGAATTGCAGAATCCCGTG AACCATCAAATCTTTGAACGCAAGTTGCGCCTGAGGCCAAT TGGCTAAGGGCACGTCCGCCTGGGCGTCAAGCATTACATCGC TTCATTCGACACCAATTGCCCAGTATTTTGCTGTGGTGCTGG TCTGAATGCGGAGAGTGGCCCTTCGTGCACACTTGTGCGACG GGTTGAAGAACAATTTGCTTTCCTCTGGCCATGTTTTGATA AAGGGGTGGTGTATGCAGCCATTAGGCCCACACTATCATCTC ATTGCCTTGAGGAGGATAAATGTACACATTCGTGGCTGATCA CCCGATATAAATGTCGCAGGTGACGCCCTGAAATGCGACCC $\mathrm{CA}$
Based on 4 sequences from the isolation, we found that the nucleotide order of the studied samples were equal (667 nucleotides); then we made a comparison with the ITS gene sequence published in GenBank as a basis for further research.

Analysis of the studied ITS sequences in comparison with the ITS sequences published in GenBank

DNASTAR software was used to compare the studied ITS sequences with the ITS sequences published in the GenBank database. The results are shown in Fig. 2.
GQ328774.seq KT344108 . seq PL1 . seg PL2. seq $\mathrm{xL} 1$. seq xL2 . seq

GQ328774 . seq KT344108. seq PL1. seq

PL2 . seq

$\mathrm{XL1}$.seq

$\mathrm{xL} 2$. seq

GQ328774.seq KT344108.seq PL1 . seq

PL2 . seq $\mathrm{XL} 1$. seq $\mathrm{XL} 2$. seq

GQ328774 . seq KT344108. seq PL1. seg PL2 . seq XL1 . seq $\mathrm{xL} 2$. seq

GQ328774 . seq KT344108. seq PL1. seg

PL2 . seg

$\mathrm{XL1}$. seq

$X L 2$.seq

GQ328774.seq KT344108.seq

PL1 . seg

PL2. seg

$\mathrm{XL} 1$. seq

$\mathrm{xL} 2$. seg

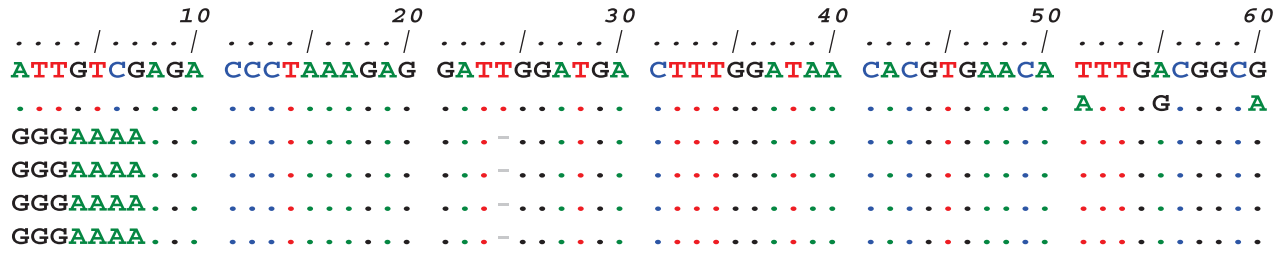

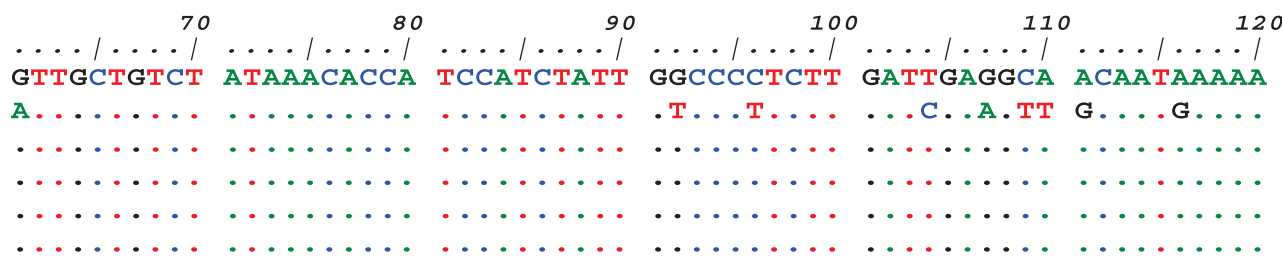

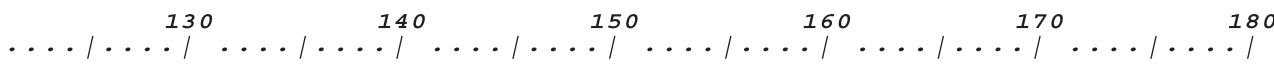
GATGGAGGGA AAAACAACTC GGGCGCAGTT GTGCGCCAAG GAAGTATGTT GCATTGGCAT

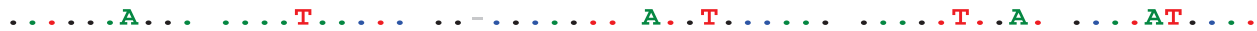

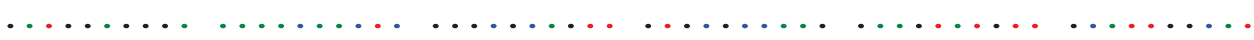

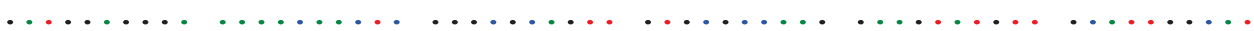

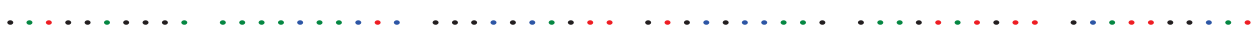

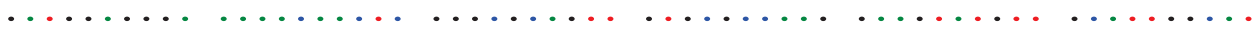

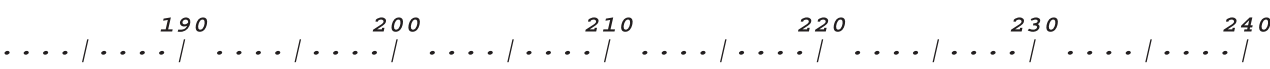
CGATGACTAT TCGCCAAAGC СTGTCGTGCT TAGCGGAGTG TTGTTGTTGC TTCTTAAGTA $\ldots \ldots$............. .... . .... с ..........

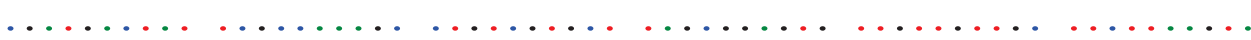

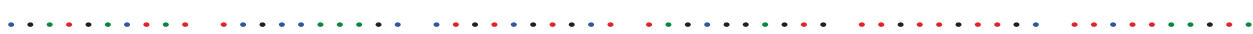

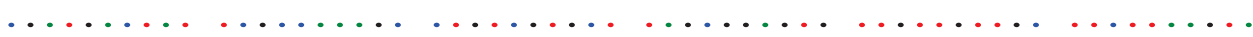

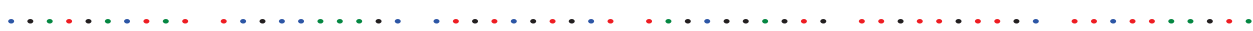

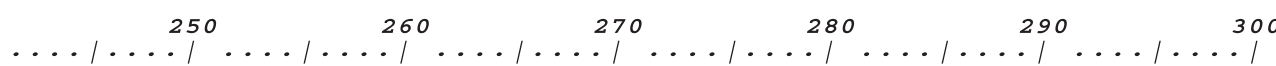
TTGTATGACT CTCGGCAATG GATATCTTGG CTCTTGCATC GATGAAGAGC GCAGCGAAAT

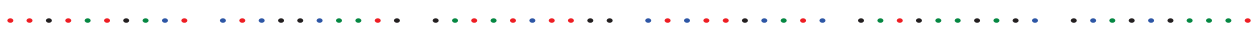

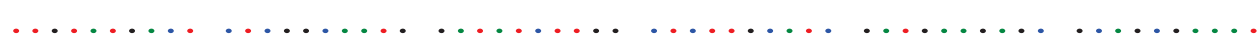

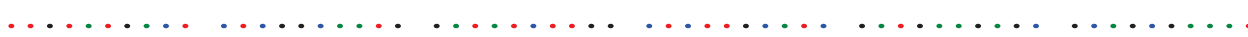

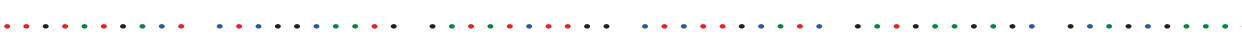

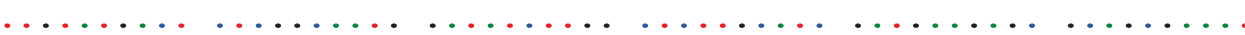

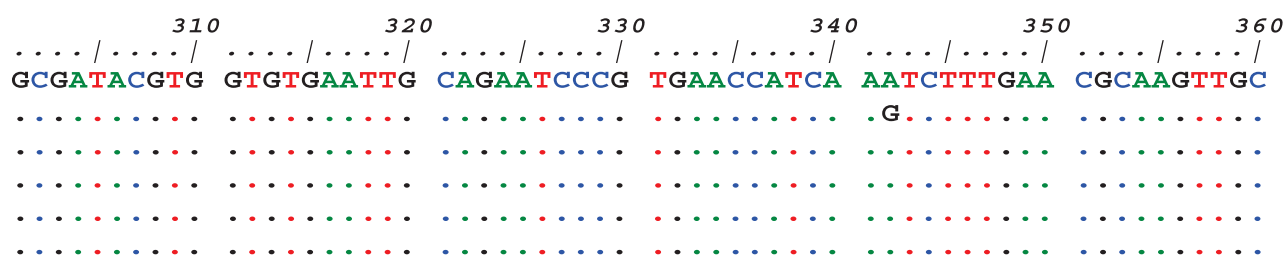

Fig. 2. Comparison among the studied ITS sequences (XL1, XL2, PL1 and PL2) with the ITS sequences in the GenBank database (GQ328774 and КT344108)

Рис. 2. Сравнительный анализ изучаемых ITS-последовательностей (XL1, XL2, PL1 и PL2) и ITS-последовательностей из базы данных GenBank (GQ328774 и KT344108) 
Go328774 . seq KT344108 . seq

PL1.seq PL2 . seq $\mathrm{XL} 1$. seq $\mathrm{xL} 2$. seq

GQ328774.seg KT344108 . seq PL1.seq PL2 . seq $\mathrm{XL} 1$. seq XL2 . seq

GQ328774 . seq KT344108.seq PL1. seq

PL2 . seq $\mathrm{XL1}$. seq $\mathrm{XL} 2$. seq

GQ328774.seg KT344108. seq PL1.seq $P L 2$. seq $\mathrm{XL1}$. seq $\mathrm{xL} 2$. seq

GQ328774.seq KT344108 . seq PL1 . seq

PL2 . seq

$\mathrm{XL} 1$. seg

$\mathrm{XL} 2$. seq

GQ328774.seq KT344108. seq $\mathrm{PL} 1$. seq

PL2 . seq

$\mathrm{XL} 1$.seq

$\mathrm{XL} 2$. seq

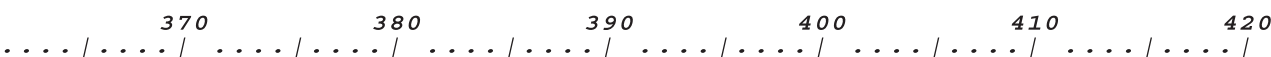
GCCTGAGGCC AATTGGCTAA GGGCACGTCC GCCTGGGCGT CAAGCATTAC ATCGCTTCAT

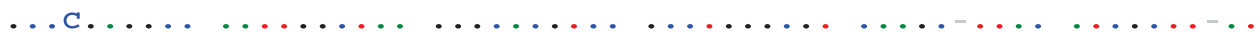

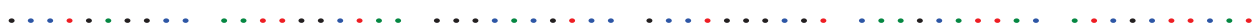
$\ldots \ldots \ldots \ldots \ldots \ldots \ldots \ldots \ldots \ldots \ldots \ldots \ldots \ldots \ldots \ldots \ldots \ldots \ldots \ldots \ldots$

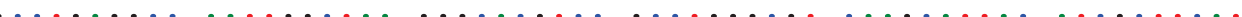

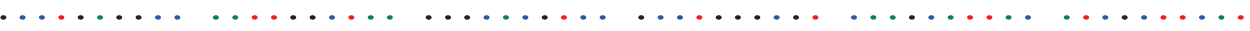

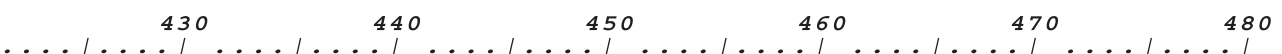
TCGACACCAA TTGCCCAGTA TTTTG-CTG TGGTGCTGGT CTGAATGCGG AGAGTGGCCC

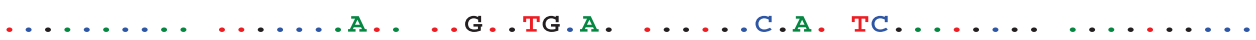

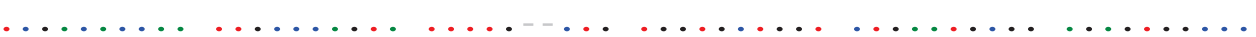

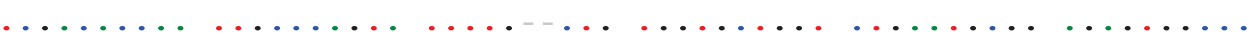

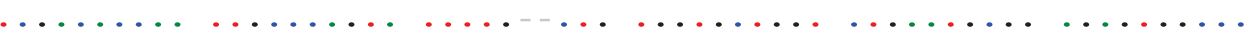

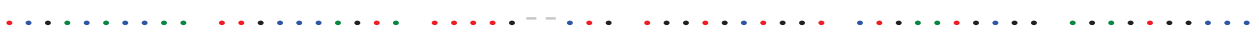

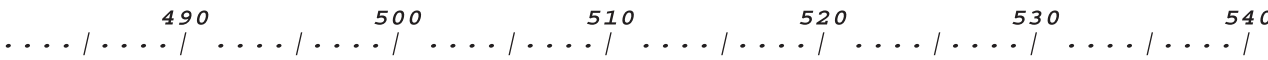
TTCGTGCACA СтTGTGCGAC GGGTTGAAGA ACAATTTGCT тTCCTCTGGC САTGTTTTGA

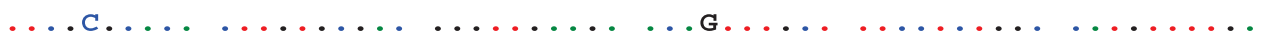

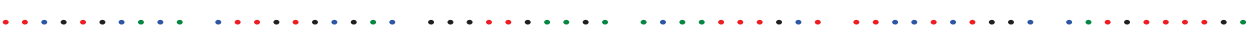

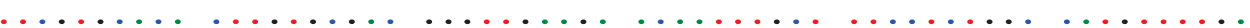

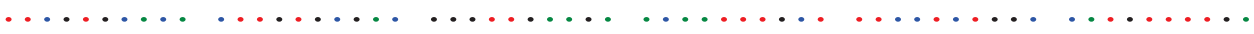

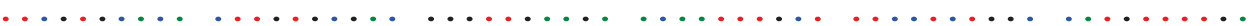

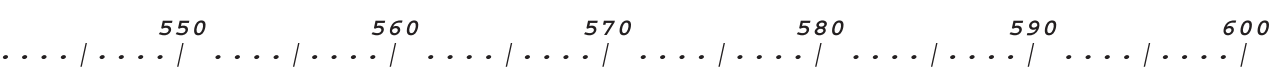
TAAAgGgGTg GTGTATGCAg CCATTAGGCC CACACTATCA TCTCATTGCC TTGAGgAgGA

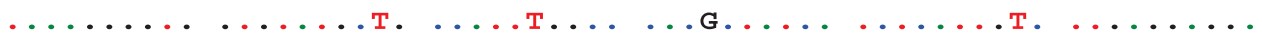

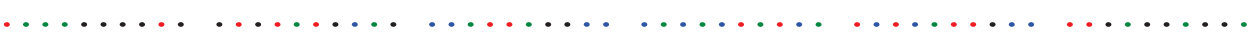

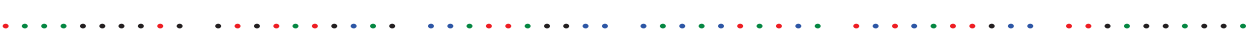

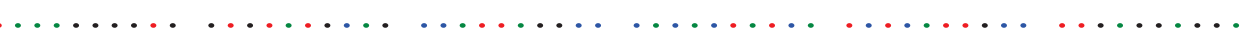

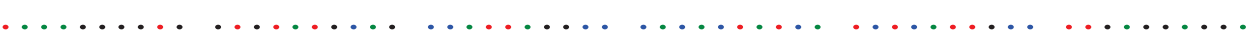

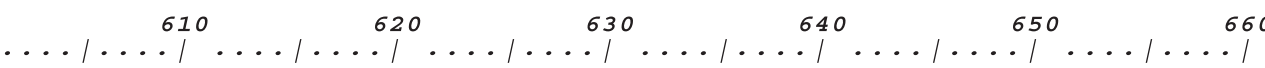
TAAATGTACA CATTCGTGGC TGATCACCCG ATATAAATGT CGCAGGTGAC GCCCTGAAAT

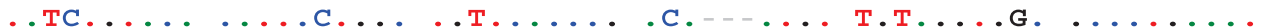

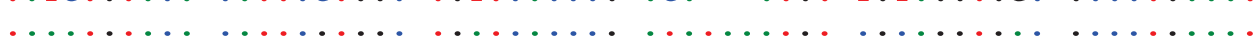

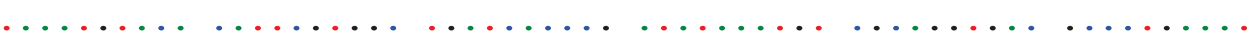

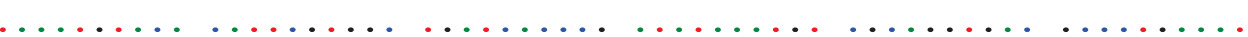

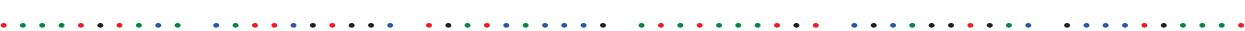

\section{$\ldots / \ldots$ \\ GCGACCCCA \\ .........

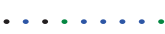 \\ ......... \\ $\cdots \ldots$}

Fig. 2 (continued). Comparison among the studied ITS sequences (XL1, XL2, PL1 and PL2) with the ITS sequences in the GenBank database (GQ328774 and KT344108)

Рис. 2 (продолжение). Сравнительный анализ изучаемых ITS-последовательностей (XL1, XL2, PL1 и PL2) и ITS-последовательностей из базы данных GenBank (GQ328774 и KT344108)

It can be seen that $A$. setaceus samples collected in $\mathrm{Pu}$ Luong (PL1 and PL2) and Xuan Lien (XL1 and XL2) had the same nucleotide order of the ITS region (Table 2), which reconfirm that the studied samples collected in Pu Luong and Xuan Lien were the same species. However, the studied ITS sequences were markedly different from an ITS sequence coded KT344108 published in GenBank. The details are presented in Table 2 .

Table 2 shows that there is a different position between the studied ITS gene sequence and the one coded GQ328774 in GenBank. To be more specific, at the 24th position of
GQ328774 there was T, while $\mathrm{G}$ was recognized at this position of the 4 A. setaceus samples. However, there were huge differences between the 4 studied ITS gene sequences and KT344108 as there were up to 50 different positions (Table 2). Therefore, it was possible to conclude that the A. setaceus samples and A. roxburghii species whose ITS gene sequence published in Genbank, GQ328774, were the same species. This also showed that the variability of the conservative nucleotide sequence of a nuclear gene (ITS) was not high among individuals of the same species (Álvarez, Wendel, 2003). 
Table 2. Differences between the studied ITS sequences (XL1, XL2, PL1 and PL2) and the ITS gene sequences in the GenBank database (GQ328774 and KT344108)

Таблица 2. Различия между изучаемыми ITS-последовательностями (XL1, XL2, PL1 и PL2) и ITS-последовательностями из базы данных GenBank (GQ328774 и КT344108)

\begin{tabular}{|c|c|c|c|c|c|c|c|}
\hline No. & Location & GQ328774 & XL1 & XL2 & PL1 & PL2 & KT344108 \\
\hline 1 & 24 & $\mathrm{~T}$ & G & G & G & G & $\mathrm{T}$ \\
\hline 2 & 51 & $\mathrm{~T}$ & G & G & G & G & A \\
\hline 3 & 55 & A & A & A & A & A & G \\
\hline 4 & 60 & G & G & G & G & G & A \\
\hline 5 & 91 & G & G & G & G & G & $\mathrm{T}$ \\
\hline 6 & 96 & $\mathrm{C}$ & $\mathrm{C}$ & $\mathrm{C}$ & $\mathrm{C}$ & $\mathrm{C}$ & $\mathrm{T}$ \\
\hline 7 & 104 & $\mathrm{~T}$ & $\mathrm{~T}$ & $\mathrm{~T}$ & $\mathrm{~T}$ & $\mathrm{~T}$ & $\mathrm{C}$ \\
\hline 8 & 107 & A & A & A & A & A & G \\
\hline 9 & 109 & $\mathrm{C}$ & $\mathrm{C}$ & $\mathrm{C}$ & $\mathrm{C}$ & $\mathrm{C}$ & $\mathrm{T}$ \\
\hline 10 & 110 & A & A & A & A & A & $\mathrm{T}$ \\
\hline 11 & 101 & A & A & A & A & A & $\mathrm{T}$ \\
\hline 12 & 111 & A & A & A & A & A & G \\
\hline 13 & 116 & A & A & A & A & A & G \\
\hline 14 & 127 & G & G & G & G & G & A \\
\hline 15 & 135 & C & C & C & C & $\mathrm{C}$ & $\mathrm{T}$ \\
\hline 16 & 151 & G & G & G & G & G & A \\
\hline 17 & 154 & $\mathrm{C}$ & $\mathrm{C}$ & $\mathrm{C}$ & $\mathrm{C}$ & $\mathrm{C}$ & $\mathrm{T}$ \\
\hline 18 & 166 & A & A & A & A & A & $\mathrm{T}$ \\
\hline 19 & 169 & $\mathrm{~T}$ & $\mathrm{~T}$ & $\mathrm{~T}$ & $\mathrm{~T}$ & $\mathrm{~T}$ & A \\
\hline 20 & 175 & $\mathrm{~T}$ & $\mathrm{~T}$ & $\mathrm{~T}$ & $\mathrm{~T}$ & $\mathrm{~T}$ & A \\
\hline 21 & 176 & G & G & $\mathrm{G}$ & $\mathrm{G}$ & G & $\mathrm{T}$ \\
\hline 22 & 186 & A & A & A & A & A & $\mathrm{G}$ \\
\hline 23 & 204 & $\mathrm{~T}$ & $\mathrm{~T}$ & $\mathrm{~T}$ & $\mathrm{~T}$ & $\mathrm{~T}$ & A \\
\hline 24 & 205 & C & C & C & C & C & $\mathrm{T}$ \\
\hline 25 & 212 & A & A & A & A & A & $\mathrm{T}$ \\
\hline 26 & 219 & $\mathrm{~T}$ & $\mathrm{~T}$ & $\mathrm{~T}$ & $\mathrm{~T}$ & $\mathrm{~T}$ & C \\
\hline 27 & 221 & $\mathrm{~T}$ & $\mathrm{~T}$ & $\mathrm{~T}$ & $\mathrm{~T}$ & $\mathrm{~T}$ & C \\
\hline 28 & 342 & A & A & A & A & A & $\mathrm{G}$ \\
\hline 29 & 364 & $\mathrm{~T}$ & $\mathrm{~T}$ & $\mathrm{~T}$ & $\mathrm{~T}$ & $\mathrm{~T}$ & C \\
\hline 30 & 438 & $\mathrm{G}$ & G & G & $\mathrm{G}$ & G & A \\
\hline 31 & 443 & $\mathrm{~T}$ & $\mathrm{~T}$ & $\mathrm{~T}$ & $\mathrm{~T}$ & $\mathrm{~T}$ & G \\
\hline 32 & 449 & $\mathrm{~T}$ & $\mathrm{~T}$ & $\mathrm{~T}$ & $\mathrm{~T}$ & $\mathrm{~T}$ & A \\
\hline 33 & 457 & $\mathrm{~T}$ & $\mathrm{~T}$ & $\mathrm{~T}$ & $\mathrm{~T}$ & $\mathrm{~T}$ & C \\
\hline 34 & 459 & G & G & G & $\mathrm{G}$ & G & A \\
\hline
\end{tabular}


Table 2. The end

Таблица 2. Окончание

\begin{tabular}{|c|c|c|c|c|c|c|c|}
\hline No. & Location & GQ328774 & XL1 & XL2 & PL1 & PL2 & KT344108 \\
\hline 35 & 461 & $\mathrm{C}$ & $\mathrm{C}$ & $\mathrm{C}$ & $\mathrm{C}$ & $\mathrm{C}$ & $\mathrm{T}$ \\
\hline 36 & 462 & $\mathrm{~T}$ & $\mathrm{~T}$ & $\mathrm{~T}$ & $\mathrm{~T}$ & $\mathrm{~T}$ & $\mathrm{C}$ \\
\hline 37 & 485 & $\mathrm{~T}$ & $\mathrm{~T}$ & $\mathrm{~T}$ & $\mathrm{~T}$ & $\mathrm{~T}$ & $\mathrm{C}$ \\
\hline 38 & 553 & A & A & A & A & A & G \\
\hline 39 & 559 & $\mathrm{~A}$ & A & A & A & A & $\mathrm{T}$ \\
\hline 40 & 566 & $\mathrm{~A}$ & A & A & A & A & $\mathrm{T}$ \\
\hline 41 & 574 & A & A & A & A & A & G \\
\hline 42 & 589 & $\mathrm{C}$ & $\mathrm{C}$ & C & $\mathrm{C}$ & $\mathrm{C}$ & $\mathrm{T}$ \\
\hline 43 & 603 & A & A & A & A & A & $\mathrm{T}$ \\
\hline 44 & 604 & $\mathrm{~A}$ & A & A & A & A & $\mathrm{C}$ \\
\hline 45 & 616 & $\mathrm{G}$ & G & G & G & G & $\mathrm{C}$ \\
\hline 46 & 623 & A & A & A & A & A & $\mathrm{T}$ \\
\hline 47 & 632 & $\mathrm{~T}$ & $\mathrm{~T}$ & $\mathrm{~T}$ & $\mathrm{~T}$ & $\mathrm{~T}$ & $\mathrm{C}$ \\
\hline 48 & 641 & $\mathrm{C}$ & $\mathrm{C}$ & $\mathrm{C}$ & $\mathrm{C}$ & $\mathrm{C}$ & $\mathrm{T}$ \\
\hline 49 & 643 & $\mathrm{C}$ & $\mathrm{C}$ & $\mathrm{C}$ & $\mathrm{C}$ & $\mathrm{C}$ & $\mathrm{T}$ \\
\hline 50 & 649 & A & A & A & A & A & G \\
\hline
\end{tabular}

The genetic relationship among the studied ITS gene sequences and the ones published in GenBank was analyzed using BioEdit software. The results are shown in Table 3 and Fig. 3.

It can be pointed out that the ITS gene sequences of $A$. setaceus samples collected at Xuan Lien (XL1 and XL2) and Pu Luong (PL1 and PL2) of Thanh Hoa were the same and similar to GQ328774 of $A$. roxburghii. The differences were very small. The genetic relationship among the samples and KT344108 (A. lanceolatus) was relatively large, as shown in Fig. 3.
The findings show that the ITS gene sequences of $A$. setaceus samples collected at Xuan Lien (XL1 and XL2) and Pu Luong (PL1 and PL2) and ITS gene sequence of A. roxburghii (GQ328774) were related to the same species and had a relatively large dissociation coefficient with A.lanceolatus (KT344108). The ITS gene sequences of $A$. setaceus samples collected at Xuan Lien (XL1 and XL2) were not genetically different from those collected in Pu Luong (PL1 and PL2). It is also proved that the method employing internal transcribed spacer (ITS) sequences is an effective tool to identify A. setaceus.

Table 3. Comparison among the studied ITS gene sequences (XL1, XL2, PL1 and PL2) with the ITS gene sequences in the GenBank database (GQ328774 and KT344108)

Таблица 3. Сравнительный анализ изучаемых ITS-последовательностей (XL1, XL2, PL1 и PL2) и ITSпоследовательностей из базы данных GenBank (GQ328774 и KT344108)

\begin{tabular}{|c|c|c|c|c|c|c|c|c|c|}
\hline \multirow{9}{*}{ 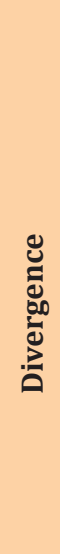 } & \multicolumn{9}{|c|}{ Percent Identity } \\
\hline & & 1 & 2 & 3 & 4 & 5 & 6 & & \multirow{4}{*}{$\begin{array}{l}\text { GQ328774.seq } \\
\text { KT344108.seq } \\
\text { PL1.seq }\end{array}$} \\
\hline & 1 & & 92.6 & 98.9 & 98.9 & 98.9 & 98.9 & 1 & \\
\hline & 2 & 7.9 & & 91.5 & 91.5 & 91.5 & 91.5 & 2 & \\
\hline & 3 & 1.1 & 9.1 & & 100.0 & 100.0 & 100.0 & 3 & \\
\hline & 4 & 1.1 & 9.1 & 0.0 & & 100.0 & 100.0 & 4 & \multirow{4}{*}{$\begin{array}{l}\text { PL2.seq } \\
\text { XL1.seq } \\
\text { XL2.seq }\end{array}$} \\
\hline & 5 & 1.1 & 9.1 & 0.0 & 0.0 & & 100.0 & 5 & \\
\hline & 6 & 1.1 & 9.1 & 0.0 & 0.0 & 0.0 & & 6 & \\
\hline & & 1 & 2 & 3 & 4 & 5 & 6 & & \\
\hline
\end{tabular}




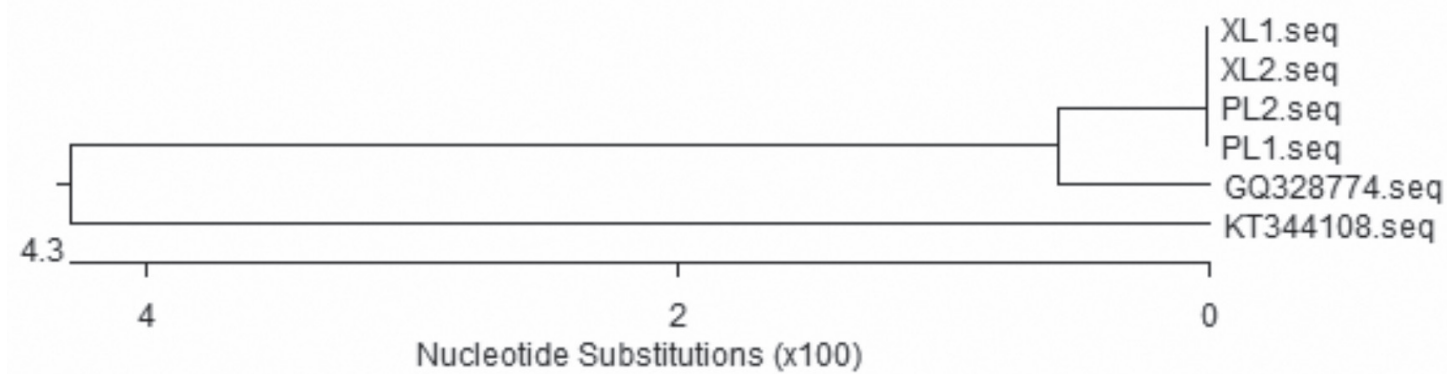

Fig. 3. Tree diagram showing the genetic relationship

between the studied ITS gene sequences (XL1, XL2, PL1 and PL2) and the ITS gene sequences published in the GenBank database

Рис. 3. «Филогенетическое древо», построенное на основе сравнения изучаемых ITS-последовательностей (XL1, XL2, PL1 и PL2) и ITS-последовательностей из базы данных GenBank

\section{Conclusion}

The ITS gene sequences of $A$. setaceus in Thanh Hoa were successfully isolated and read in this study; the studied ITS gene was 667 nucleotides long and 99\% similar to the ITS gene sequence of $A$. roxburghii published in GenBank, GQ328774. The study results also showed that the ITS gene sequences of $A$. setaceus samples collected at Xuan Lien (XL1 and XL2) and Pu Luong (PL1 and PL2) of Thanh Hoa province were not different, which meant the samples belonged to the same species.

\section{References}

Álvarez I., Wendel J.F. Ribosomal ITS sequences and plant phylogenetic inference. Molecular Phylogenetics and Evolution. 2003;29(3):417-434. DOI: $10.1016 /$ S10557903(03)00208-2

Baldwin B.G., Sanderson M.J., Porter J.M., Wojciechowski M.F., Campbell C.S., Donoghue M.J. The ITS region of nuclear ribosomal DNA: a valuable source of evidence on angiosperm phylogeny. Annals of the Missouri Botanical Garden. 1995;82(2):247-277. DOI: 10.2307/2399880

Chac L.D., Thinh B.B., Huong H.T.T., Kiet N.T., Huan L.Q. Quantification of quercetin, isorhamnetin and ferulic acid in dry extract of Anoectochilus setaceus Blume from Vietnam. International Journal of Botany Studies. 2019;4(5):14-18.

Chen J.R., Shiau Y.J. Application of internal transcribed spacers and maturase $\mathrm{K}$ markers for identifying Anoectochilus, Ludisia, and Ludochilus. Biologia Plantarum. 2015;59(3):485-490. DOI: 10.1007/s10535-015-0520-3

Doyle J.J., Doyle J.L. A rapid DNA isolation procedure for small quantities of fresh leaf tissue. Phytochemistry Bulletin. 1987;19(1):11-15.

Gigliano S.S. Preliminary data on the usefulness of internal transcribed spacer I (ITS1) sequence in Cannabis sativa L. identification. Journal of Forensic Science. 1999;44(3):475477. DOI: $10.1520 / J F S 14497 J$

He C.N., Wang C.L., Guo S.X., Yang J.S., Xiao P.G. A novel flavonoid glucoside from Anoectochilus roxburghii (Wall.) Lindl. Journal of Integrative Plant Biology. 2006;48(3):359363. DOI: 10.1111/j.1744-7909.2006.00179.x

Hu S.J., Hu H.Y., Gao H.., Liu X., Chen S.L. DNA barcoding and rapid identification of the precious herb Herba Anoectochili. Chinese Journal of Natural Medicines. 2019;17(10):738-745. DOI: 10.1016/S1875-5364(19)30090-1
Kress W.J., Wurdack K.J., Zimmer E.A., Weigt L.A., Janzen D.H. Use of DNA barcodes to identify flowering plants. Proceedings of the National Academy of Sciences. 2005;102(23):8369-8374. DOI: 10.1073/pnas.0503123102

Li D.Z., Gao L.M., Li H.T., Wang H., Ge X.J., Liu J.Q. et al. Comparative analysis of a large dataset indicates that internal transcribed spacer (ITS) should be incorporated into the core barcode for seed plants. Proceedings of the National Academy of Sciences. 2011;108(49):19641-19646. DOI: $10.1073 /$ pnas. 1104551108

Li M., Cao H., But P.P.H., Shaw P.C. Identification of herbal medicinal materials using DNA barcodes. Journal of Systematics and Evolution. 2011;49(3):271-283. DOI: 10.1111/j.1759-6831.2011.00132.x

Lin J.M., Lin C.C., Chiu H.F., Yang J.J., Lee S.G. Evaluation of the anti-inflammatory and liver-protective effects of Anoectochilus formosanus, Ganoderma lucidum and Gynostemma pentaphyllum in rats. The American Journal of Chinese Medicine. 1993;21(01):59-69. DOI: 10.1142/ S0192415X9300008X

Lin C.C., Huang P.C., Lin J.M. Antioxidant and hepatoprotective effects of Anoectochilus formosanus and Gynostemma pentaphyllum. The American Journal of Chinese Medicine. 2000;28(01):87-96. DOI: 10.1142/S0192415X00000118

Lv T., Teng R., Shao Q., Wang H., Zhang W., Li M. et al. DNA barcodes for the identification of Anoectochilus roxburghii and its adulterants. Planta. 2015;242(5):1167-1174. DOI: $10.1007 / \mathrm{s} 00425-015-2353-\mathrm{x}$

Stoeckle M. Taxonomy, DNA, and the bar code of life. BioScience. 2003;53(9):796-797. DOI: 10.1641/0006-3568(2003)053[0796:TDATBC]2.0.C0;2

Takamiya T., Wongsawad P., Tajima N., Shioda N., Lu J.F., Wen C.L. et al. Identification of Dendrobium species used for herbal medicines based on ribosomal DNA internal transcribed spacer sequence. Biological and Pharmaceutical Bulletin. 2011;34(5):779-782. DOI: 10.1248/ bpb.34.779

Techen N., Parveen I., Pan Z., Khan I.A. DNA barcoding of medicinal plant material for identification. Current Opinion in Biotechnology. 2014;25:103-110. DOI: 10.1016/j. copbio.2013.09.010

Tripathi A.M., Tyagi A., Kumar A., Singh A., Singh S., Chaudhary L.B. et al. The internal transcribed spacer (ITS) region and trnhH-psbA are suitable candidate loci for DNA barcoding of tropical tree species of India. PLOS ONE. 2013;8(2):e57934. DOI: 10.1371/journal. pone.0057934 
Vietnam Academy of Science and Technology. Vietnam Red Data Book, Part II. Plants. Hanoi: Natural Science and Technology Publish. House; 2007. [in Vietnamese]

Wang S.Y., Kuo Y.H., Chang H.N., Kang P.L., Tsay H.S., Lin K.F. et al. Profiling and characterization antioxidant activities in Anoectochilus formosanus Hayata. Journal of Agricultural and Food Chemistry. 2002;50(7):1859-1865. DOI: $10.1021 /$ jf0113575

Wang X., Xue J., Zhang Y., Xie H., Wang Y., Weng W. et al. DNA barcodes for the identification of Stephania
(Menispermaceae) species. Molecular Biology Reports. 2020;47:2197-2203. DOI: 10.1007/s11033-020-05325-6

Yang J.B., Wang Y.P., Möller M., Gao L.M., Wu D. Applying plant DNA barcodes to identify species of Parnassia (Parnassiaceae). Molecular Ecology Resources. 2012;12(2):267-275. DOI: 10.1111/j.1755-0998.2011.03095.x

Ye S., Shao Q., Zhang A. Anoectochilus roxburghii: A review of its phytochemistry, pharmacology, and clinical applications. Journal of Ethnopharmacology. 2017;209:184-202. DOI: 10.1016/j.jep.2017.07.032
Прозрачность финансовой деятельности / The transparency of financial activities

Авторы не имеют финансовой заинтересованности в представленных материалах или методах.

The authors declare the absence of any financial interest in the materials or methods presented.

\section{Для цитирования / How to cite this article}

Тхинь Б.Б., Чак Л.Д., Тху Л.Т.М. Применение последовательностей внутренних транскрибируемых спейсеров (ITS) для идентификации образцов Anoectochilus setaceus Blume в Тханьхоа (Вьетнам). Труды по прикладной ботанике, генетике и селекции. 2020;181(2):108-116. DOI: 10.30901/2227-8834-2020-2-108-116

Thinh B.B., Chac L.D., Thu L.T.M. Application of internal transcribed spacer (ITS) sequences for identifying Anoectochilus setaceus Blume in Thanh Hoa, Vietnam. Proceedings on Applied Botany, Genetics and Breeding. 2020;181(2):108-116. DOI: 10.30901/2227-8834-2020-2108-116
Авторы благодарят рецензентов за их вклад в экспертную оценку этой работы / The authors thank the reviewers for their contribution to the peer review of this work

Дополнительная информация / Additional information

Полные данные этой статьи доступны / Extended data is available for this paper at https://doi.org/10.30901/2227-8834-2020-2-108-116

Мнение журнала нейтрально к изложенным материалам, авторам и их месту работы / The journal's opinion is neutral to the presented materials, the authors, and their employer

Все авторы одобрили рукопись / All authors approved the manuscript

Конфликт интересов отсутствует / No conflict of interest

ORCID

Thinh B.B. https://orcid.org/0000-0002-3826-1199

Chac L.D. https://orcid.org/0000-0002-0845-4678

Thu L.T.M. https://orcid.org/0000-0002-3872-996X 